first in Debtors in Court, and became the centerpiece of the analysis of plea-bargaining in Felony Justice. His description of the ways in which long-standing interpersonal relationships among defense attorneys, prosecutors, and judges influence the process by which cases are resolved and the outcomes that are produced became a central concept in the extensive study of plea-bargaining that followed.

His 1988 book, Silent Revolution, traced the diffusion of divorce reform across the United States, and explored the mystery of the rapid rise and spread of "no fault" divorce. The book was based on documentary evidence and interviews with state legislators, lobbyists, and other participants. Herb was intrigued by the fact that this major legal change did not seem to be characterized by the sponsorship and promotion by interest groups that typically accompanied more noisy legal revolutions. Indeed, what interest group activity there was, mainly by the Catholic Church, opposed rather than supported the adoption of new procedures that made divorce easier to obtain. Rather, he suggests, the reform was the product of a good deal of "unorganized" but quite effective informal exchanging of information, much of it anecdotal, among members of state legislatures, both within states and among them. His study suggests that sometimes rapid legal change occurs, as it were, by a kind of spontaneous combustion (following rapid social change, requiring neither central authority nor the investment of substantial material resources. Prior work tended to suggest that these were necessary conditions for successful diffusion. But this innovative book deepens and critiques our understanding of the way in which legal change comes about.

His body of scholarship is a major legacy to the field of law and politics, but Herb left us with much more than his insights and findings. He was a person of great intelligence and energy, combined with the inclination to share his ideas and strength with others. These "others" included his students and his colleagues all over the world. Herb was a dedicated teacher of undergradu- ates who was a pioneer in the use of computer technology in teaching. His many graduate students who have gone on to distinguished careers in political science and criminal justice attest to his commitment to their education and to nurturing them through graduate school and into the academic world. His mentoring came not only from what he said to his students or wrote to them in comments on their work. He taught them by his own example. He was serious about his work, always thinking about his next project, and always engaged in more than one project at any particular time. He was a model not only for his students, but for his colleagues as well.

Herb was a wonderful colleague. He was active in both intellectual and academic politics in his department. He was a person with strong opinions about what were good ideas and bad ones, good policies and silly ones. We are all familiar with the aphorism about academic politics that "Never is the politics so intense as when the stakes are so small," and we have all seen too many examples of this principle at work. Herb, however, did not go about his business in this fashion. He worked hard to further the positions that he believed in, and spoke his mind clearly, even when he as in the minority. But he not only knew how to win arguments, but also how to lose them as well. When he did not prevail, he did not continue gnawing at an issue, but turned without subsequent rancor to something new, willing to accept the fact that he had not won the argument. Herb gave of himself to colleagues both intellectually and personally and was admired and often loved by those who had the opportunity to work with him.

Herb was not simply an academic consumed by his research, writing, and teaching. He had an active mind and wide-ranging interests which extended far beyond his profession. His family-his wife Lynn and his four children Joel, David, Jenny, and Max-were the center of his life. Like many, the Jacobs were a family that had gradually become distant geographically as the kids grew and went off on their own paths, but they remained close in love and spirit. In addition to hiking, camping, and touring with his family, Herb loved music, theater, swimming, politics, and sailing, and many happy days and weeks sharing these activities with his family both in Chicago and all over the world.

Herb leaves behind not only his scholarship and teaching but a legacy of warmth and friendship shared with many of us. His many friends in our discipline and the law and society movement will miss him greatly.

Jonathan D. Casper Northwestern University

\section{Stafford Gorman Whittle Johnston}

Stafford Gorman Whittle Johnston of the University of Virginia died on August 26, 1996 after a long and courageous struggle with cancer. Whittle Johnston was born in Roanoke, Virginia on November 14, 1927. After serving in the United States Navy during the Second World War, he pursued his undergraduate studies at the University of Chicago and Swarthmore College where he was elected to Phi Beta Kappa. He completed his doctorate in Government at Harvard University in 1959. His Ph.D. dissertation, entitled The Primacy of Justice: $A$ Study of Liberalism and Its Role in World Politics, was awarded Harvard University's Sumner Prize for the best dissertation in international relations that year. Johnston's major fields of study were contemporary American foreign policy and modern international politics and theory. He is the author of several dozen scholarly articles, contributions to books, and opinion pieces for local and regional newspapers.

Johnston served on the faculty of the School of International Service at American University in Washington, D.C. from 1959 to 1971 . He also taught at Swarthmore College (1964) and at Johns Hopkins University (1968) as a visiting faculty member. He joined the faculty of the Department of Government and Foreign Affairs at the University of Virginia in 1971 and served there until his retirement in 1995. 
Johnston was actively engaged in a number of organizations and activities over the course of his career including service as a consulting editor to both Teaching Political Science-Politics in Perspective and World Affairs, Academic Associate at the Ethics and Public Policy Center, member of the Academic Advisory Board of the United States Naval Academy, and chairman of the American Political Science Association's Helen Dwight Reid Award committee to select the best doctoral dissertation in international relations in 1987-88.

To those of us who were fortunate enough to know Whittle Johnston as a teacher, colleague, or friend it is clear that the contribution he made to the study of political science cannot be adequately assessed or summed up through a formal listing of conventional academic honors and awards. He loved all aspects of the scholarly life, but the one he cared most about was his role as a teacher. The testimony of many of Johnston's former students, provides an important perspective on the vital and enduring contribution Whittle Johnston made to his profession.

Whittle Johnston was admired by his students, first and foremost, as a man of great virtue and the highest moral character. Innumerable students have testified to his unshakeable personal and professional integrity. He was a man of great dignity, sincere compassion, unsurpassed charm, and unerring wit. He lived his life according to the principles of the Christian gentleman. Johnston taught invaluable lessons-as much through the example and strength of his character as through his lectures and writings.

Johnston was a dynamic and tremendously gifted teacher who pursued his craft with an extraordinarily high level of dedication and hard work. One clear and deeply appreciated indication of his devotion to teaching was the great amount of time and energy he gave to individual students. Despite teaching in one of the largest departments in a major university, he made every effort to get to know the backgrounds and interests of his students so that he could respond to their concerns in seminar discussions and lectures. $\mathrm{He}$ held his students to a very high standard of academic performance, but this never diminished the tremendous popularity of his courses.

Johnston managed to defy the (otherwise) iron law of higher education that suggests an inverse relationship between grading standards and student enrollment. While he pushed and prodded his students to work to the best of their abilities, he never failed to treat each with great courtesy, fairness, patience, and respect.

Whittle Johnston's active involvement in student life at UVA is suggested by the fact that several student organizations, including the Raven and Jefferson Societies, "drafted" him into their ranks as a member; and he served as faculty adviser to the Virginia Advocate magazine at the request of that publication's student staff. Upon his retirement from the University of Virginia it was announced that a gift providing a graduate fellowship in his name had been established.

Johnston's commitment and ability as a teacher was also evident in the extraordinarily high quality of his classroom lectures. A dynamic and supremely gifted lecturer, Johnston could deftly handle even the most complex political and theoretical issues with great eloquence, clarity, and wit. He possessed a remarkable talent for public speaking and a brilliant command of the English language.

Johnston's highly polished style, however, never overshadowed the substance of his analyses. He combined a remarkable range of factual and historical knowledge with great depth of political and philosophical insight. He always maintained a healthy skepticism toward those who offer easy answers to the dilemmas of world politics. He maintained a keen awareness of the enormous difficulty and complexity of such problems-and he sought to instill that same awareness and appreciation in his students. In an analysis of Woodrow Wilson as political thinker, Johnston wrote that the 28 th president was "always moving, always adapting, always learning, always growing"; in that brief description one perhaps catches a small but illuminating glimpse of Johnston himself as scholar.
Whittle Johnston's scholarship was rooted in the careful and continuous study of modern history and the broader Western philosophical and theological traditions. He possessed a formidable command of factual and historical knowledge, but he offered no mere description of the vagaries of American foreign policy in his lectures and writings. Johnston was not concerned with "small answers to small questions," but with "broad answers to large questions." In terms of his general approach to the study of politics, Johnston rejected Enlightenment utopianism and its more recent variants on the conviction that a "harmony of interests is not natural and progress in history is not inevitable." He hastened to add, however, that disillusion with the promises of Enlightenment utopianism must not lead to an embrace of Nietzschean and Heideggerian nihilism as an alternative. Johnston's approach to the study of politics was rooted, at its deepest level, in a Christian understanding of human reality which rejected both of these extremes. Against the illusions of the utopians, he offered the sober reminder that "the Kingdom of Man, at all times and places, is distinct from the Kingdom of God" and that "all ages are equidistant from eternity." Against the hopelessness of the nihilists he offered the admonishment that "we should constantly strive to moderate conflict in the interests of order, justice, and freedom." Johnston defined the ultimate task of our profession as the attempt to find the means of building a somewhat more civilized life among humankind. In pursuit of this goal we must affirm the reality of the transcendent order and seek guidance in the study of history as "our greatest source of potential insight" and in the leading figures of the Western tradition-especially Aristotle, St. Augustine, Edmund Burke, James Madison, and Reinhold Niebuhr.

In such writings as "E.H. Carr's Theory of International Relations: A Critique" (Journal of Politics, November 1967), "Ethics, Power, and U.S. Foreign Policy" (in Christianity and Politics, ed. Griffith, 1981), and "Reflections on Wilson and the Problems of World Peace" (in Woodrow Wilson and a Revolutionary 
World, 1913-1921, ed. Link, 1982) Johnston carefully explored the truly important and enduring questions about international politics. These writings delve into such issues as the nature of man and of politics, the relationship between self-interest and the common good, the balance between justice and order, the cultural and historical roots of state behavior, the historic struggle in the modern state system between the preservation of state independence and the drive for hegemony, and the bases of durable peace among nations. Drawing from a strong background in American studies in such writings as "Little America-Big America" (Yale Review Fall 1968) and "Security and American Diplomacy" (in America's World Role in the Seventies, ed. Said, 1970), Johnston set out the defining ideas and experiences which shaped America's political culture and set this country apart from all others. His more particular analyses, such as "Franklin Roosevelt and the Wartime Strategy for Peace" (in Traditions and Values: American Diplomacy, 1865-1945, ed. Graebner, 1985), and "The Reagan Revolution and German Democracy" (in Shepherd of Democracy? ed. Hodge \& Nolan, 1992) are carefully set within a broad and illuminating historical and philosophical context. While Johnston regarded the collapse of the Soviet Union and of the ideological threat of communism as a tremendous victory for the United States, he looked at recent trends in American foreign policy with grave concern as, for example, in "Ancient Blood Feuds Underlie Bosnia Issue" (Richmond Times-Dispatch March 10, 1996). He believed that the United States, lacking a moral and cultural compass, was dangerously adrift in the post-Cold War world.

For a great many students and colleagues, the "UVA experience" has been immeasurably diminished by Johnston's premature retirement and untimely death. Although we deeply mourn his passing, we take comfort from the fact that he remains "accessible"-both to us and to new generations of students-through his scholarship. The personal integrity of the man is manifest in the steady judgment and fierce independence of mind that he brought to analysis of political issues. It is especially fitting that he spent most of his career teaching at Thomas Jefferson's university; Johnston was renowned for his commitment to the search for truth irrespective of the personal or political consequences, his devotion to the United States and the Jeffersonian principles of human freedom and individual liberty upon which it was founded, and his "eternal hostility against every form of tyranny over the mind of man." He once noted that the Reagan administration achieved many of its foreign policy successes, such as the INF Treaty, not by accommodating the conventional wisdom on arms control but by firmly resisting very heavy political, diplomatic, and media pressures for the sake of achieving a durable and worthwhile agreement. Johnston followed a broadly similar approach in his scholarship; such writings as "Radical Revisionism and the Disintegration of the American Foreign Policy Consensus" (Orbis, Spring 1976) and "The Containment of John Gaddis" (The National Interest, Winter 1986/87), among a great many others, clearly show that Johnston never trimmed his judgments to bring them into accord with the conventional wisdom of the academy. And because he never sought to be "in fashion" at the expense of the pursuit of truth, his scholarship will never be out of fashion either. Built on the firmest of foundations, Whittle Johnston's scholarship will continue to draw attention, admiration and respect for as long as serious students are engaged in the study of American foreign policy and international politics.

Whittle Johnston often described his family as "the greatest of blessings given to me." $\mathrm{He}$ is survived by Martha Stickney Johnston, his beloved wife and devoted companion of 40 years. "Without Martha", he always insisted, "nothing would have been possible." Johnston is also survived by his daughter Caithness and her husband Russell, his daughter Ruth and her husband Brandt, his son Stafford and his wife Susan and their three children. He is also survived by his brother James and his family. His many friends at UVA and around the country miss him deeply and send their condolences to the Johnston family.

David C. Jordan

Jonathan G. Rice

Robert F. Turner

Michael F. Cairo

University of Virginia

Christina K. Smith

Huntington College

\section{Charles H. Kunsman}

Charles H. Kunsman, Jr., Professor Emeritus of Political Science at San Jose State University, passed away this past summer.

Kunsman was born in the District of Columbia in 1924. He was a triple graduate of the University of California, Berkeley, receiving his bachelor's degree in 1949, a master's in 1955 and his Ph.D in 1963. He served in the Army Air Corp from 1943 to 1946.

Kunsman taught at the University of Nevada, Reno, and served for several sessions as an assistant clerk and researcher of the California State Assembly before his appointment at SJSU in 1961. He retired in early 1996 . His courses were mainly in the field of comparative governments, such as the politics and government of Canada and Scandinavia.

Kunsman's intellectual interest in these subjects never flagged. He continued to research and write papers for scholarly conferences and to travel to observe electoral politics elsewhere. He recently returned from such a visit to British Columbia much excited by a close election campaign. Kunsman was also renowned as a jovial host and for his extensive knowledge of the pubs of Canada and England.

A past president of the Northern California Political Science Association, Kunsman was also a member of several professional organizations and the Saratoga Men's Club.

Theodore Norton

San Jose State University

\section{Sam Postbrief}

Sam Postbrief died on October 17, 1996, at the age of 49 . He was riding his bike late that night near his home in Scituate, Massachusetts, 